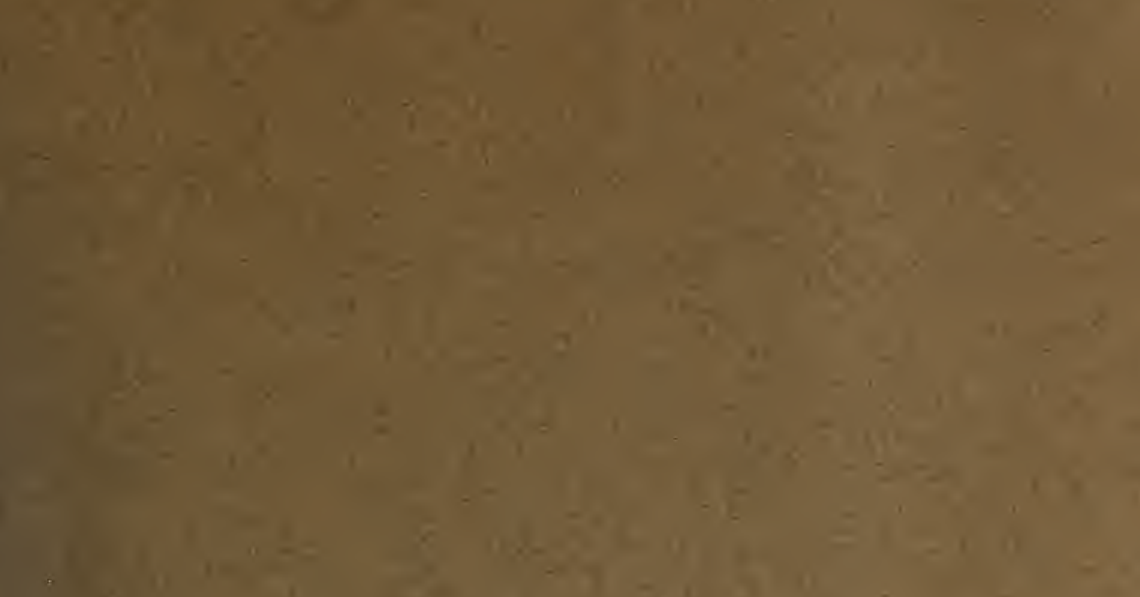

*

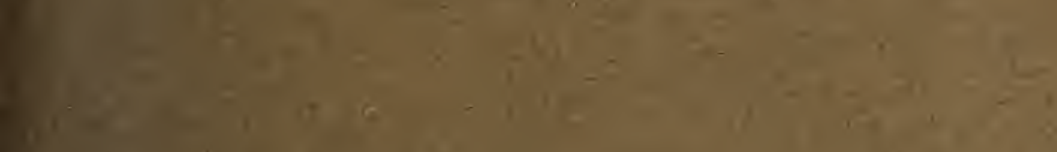

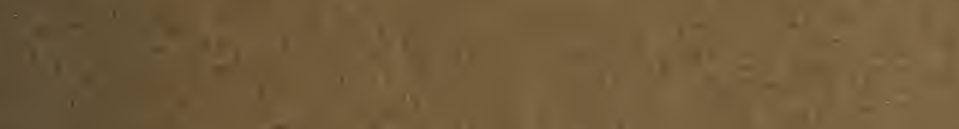

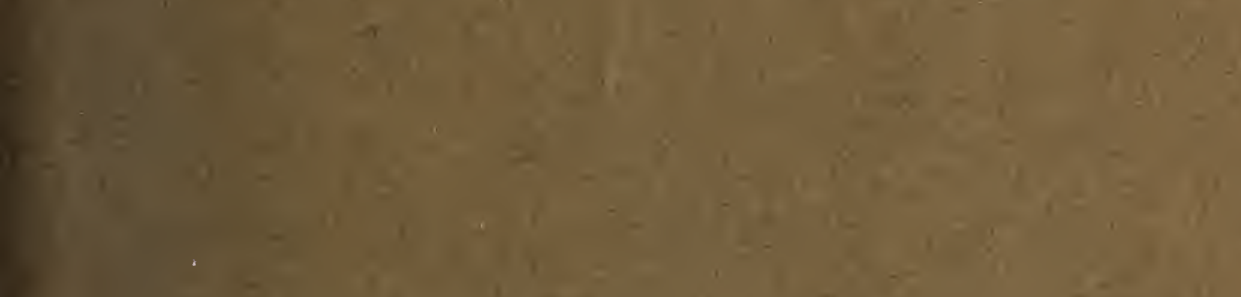

$y$

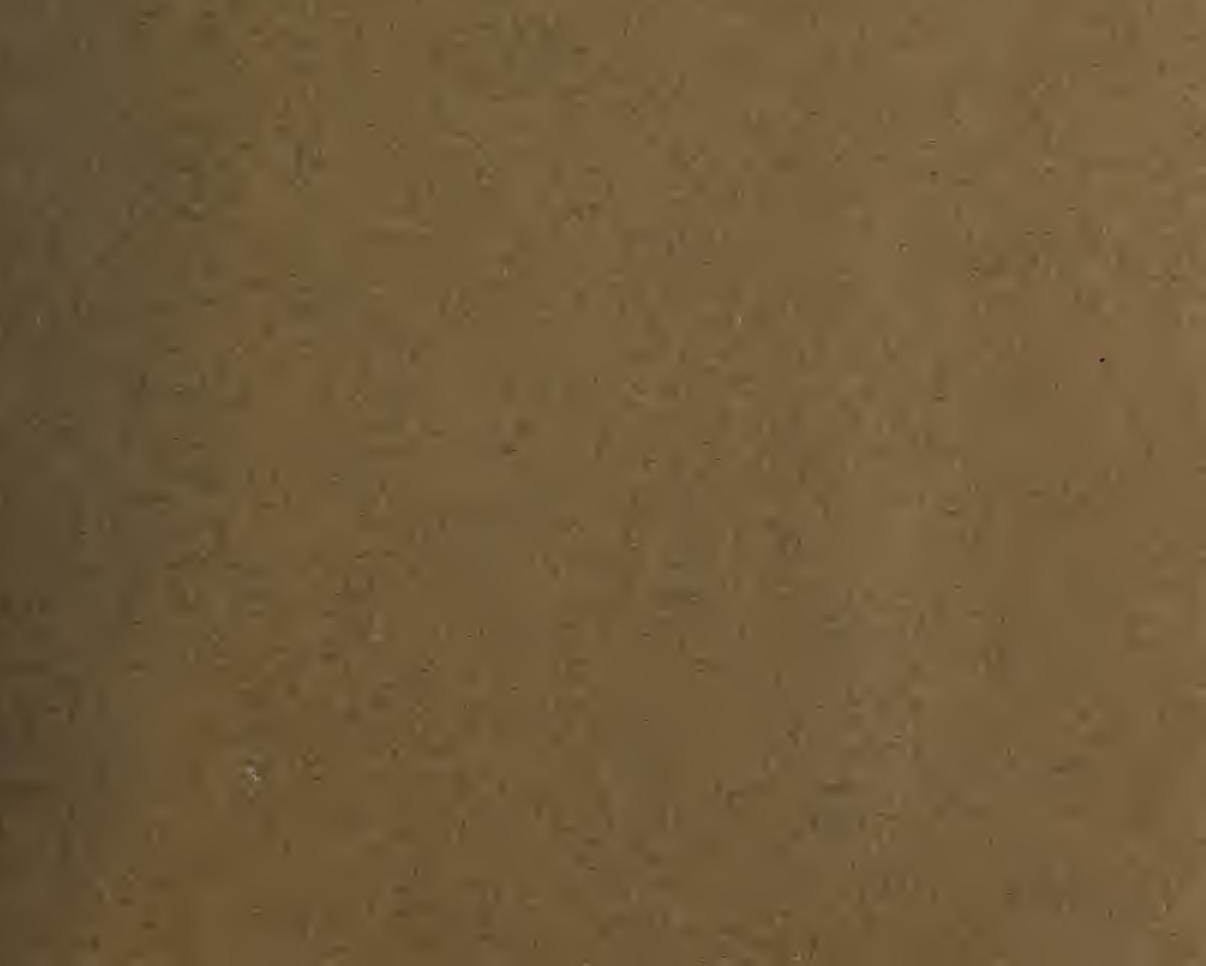





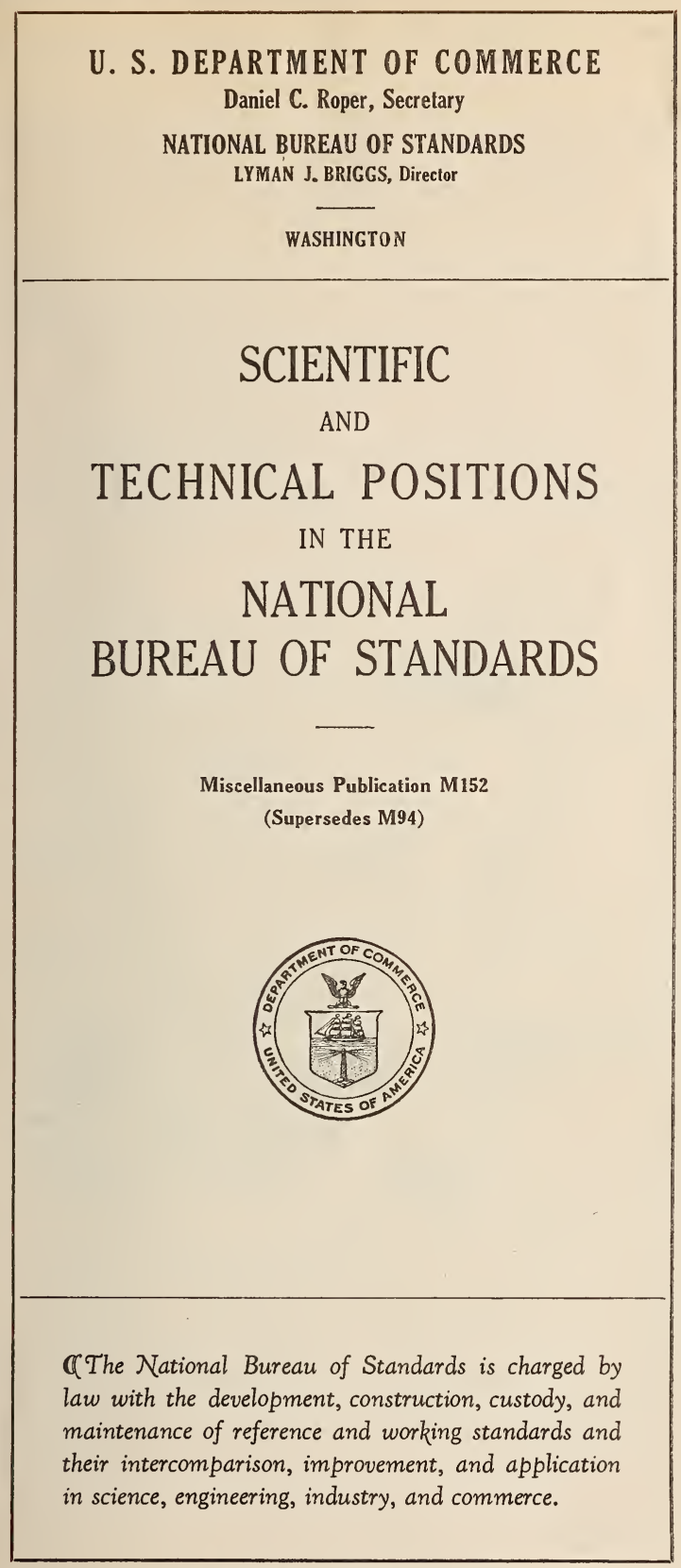

U. S. GOVERNMENT PRINTING OFFICE: 1935 


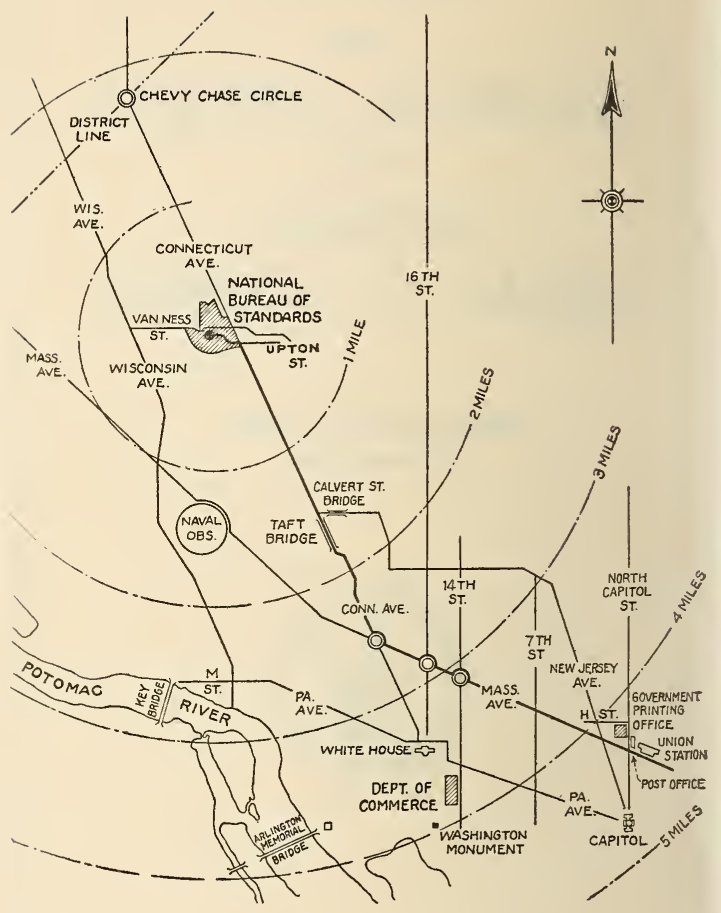




\section{SCIENTIFIC AND TECHNICAL POSITIONS in the NATIONAL BUREAU OF STANDARDS 1}

\section{CONTENTS}

Page

Subjects of Bureau activities

Purpose of this circular

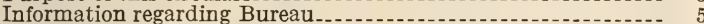

Location of Bureau

Map showing location of Bureau.-....

Airplane view of Bureau........ 10

Laboratory facilities....

Scientific and technical work

Training in the Bureau.......... 6

Educational opportunities.--_-_- 6

Library facilities...................

Information regarding appointments.-

Mode of entrance appointe.

Needs of the service

Entrance salary

Duties

Application-

Examination

Notice of examination

Physical examination

Member of family already in Government..........

Senior students...................

Citizenship and sex

Residence and domicile

Temporary appointment

Summer appointment

Research associate positions

Nontechnical positions.

Probationary period

Qualifications required for entrance---

Junior professional grade.......... 13

Physicist............ 13

Chemist-..-13

Technologist............ 13

Engineer

Assistant professional grade ........................ 14

Associate professional grade

Full professional grade

Higher professional grades........ 15

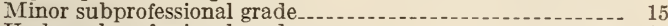

Under subprofessional grade-_......

Junior subprofessional grade

Assistant subprofessional grade

Higher subprofessional grades

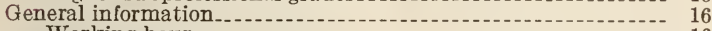

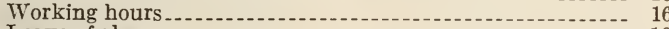

Leave of absence........... 16

Advancement ......... 16

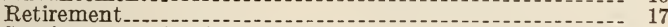

Specimen examination papers._.

Transportation to new appointees

Welfare

Recreation

Cost of living in Washington

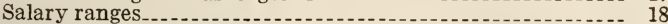

1 Prepared by William C. Fewell, Personnel Officer. 


\section{SUBJECTS OF BUREAU ACTIVITIES}

\section{Electricity}

Resistance Measurements

Inductance 8 Capacitance

Electrical Instruments

Magnetic Measurements

Photometry

Radio

Underground Corrosion

Electrochemistry

Telephone Standards

Weights and Measures

Length

Mass

Time

Capacity \& Density

Gas Measuring Insts.

Thermal Expansion, Dental Mtls., \& Identification

Weights $\&$ Meas. Laws Adm. Railroad Scales \& Test Cars Gage Standardization

\section{Heat and Power}

Thermometry

Pyrometry

Heat Measurements

Heat Transfer

Cryogenic Laboratory

Automotive Power Plants

Lubrication \& Liq. Fuels

\section{Optics}

Spectroscopy

Polarimetry

Colorimetry

Optical Instruments

Radiometry

Atomic Physics, Radium, \& X-Rays

Photographic Technology

Interferometry

\section{Chemistry}

Physico-Chemical Research Paints, Varnishes, Etc.

Detergents, Cement, Etc.

Organic Chemistry

Metal \& Ore Analysis, Etc.

Reagents 86 Platinum Metal

Electrochemistry (Plating)

Gas Chemistry

\section{Mechanics and Sound}

Engineering Instruments \& Mech. Appliances

Sound

Aeronautic Instruments

Aerodynamical Physics

Engineering Mechanics

Hydraulic Laboratory

\section{Organic \& Fibrous Ma-} terials

Rubber

Textiles

Paper

Leather

Testing $8 \approx$ Specifications

Fiber Structure

\section{Metallurgy}

Optical Metallurgy

Thermal Metallurgy

Mechanical Metallurgy

Chemical Metallurgy

Experimental Foundry

\section{Clay \& Silicate Prod-} ucts

Whiteware

Glass

Refractories

Enameled Metals

Heavy Clay Products

Cement \& Concreting!Mtls.

Masonry Construction

Lime \& Gypsum!

Stone

\section{Simplified Practice}

Wood, Textiles, \& Paper

Metal Products \& Construction Materials

Containers \& Miscellaneous Products

Materials Handling Equipment \& Ceramics

\section{Trade Standards}

Wood, Wood Products, Paper, Leather, \& Rubber Metal Products

Textiles 8 Garments

Ceramic \& Cement Prods.

Petroleum, Chemical, \& Miscellaneous Prods.

\section{Codes and Specifica-} tions

Safety Codes

Building Codes

Building Practice and Specifications

Producer Contacts and Certification

Consumer Contacts and $\mathrm{La}$. beling 
Subjects of Bureau Activities (continued)-

\begin{tabular}{l|l} 
Office & $\begin{array}{l}\text { Operation of Plant } \\
\text { Power Plant } \\
\text { Finance }\end{array}$ \\
Personnel & Plectrical \\
Purchase \& Stores & Piping \\
Property 86 Transportation & Grounds \\
Mail \& Files & Construction \\
Library & Guard \\
Information & Janitorial \\
Medical Office & \\
Shops & \\
Instrument & \\
Woodworking & \\
Glassblowing & \\
Gage & \\
Construction Stores \& Tool & \\
Room &
\end{tabular}

\section{PURPOSE OF THIS CIRCULAR}

The National Bureau of Standards desires to keep in touch with men and women who are well qualified to fill positions on its scientific staff. The aim of this circular is to answer queries received in the daily mail and give general information to prospective applicants who are interested in the scientific and technical work of the Bureau.

\section{INFORMATION CONCERNING BUREAU}

\section{Location of National Bureau}

The Bureau's location is pleasant, about $3 \frac{1}{2}$ miles from the center of Washington, at Connecticut Avenue and Upton Street. The Bureau comprises a group of laboratory buildings on a 56-acre site, arranged like a university, situated on a natural hill amidst beautiful country surroundings.

\section{Laboratory Facilities}

The Bureau's facilities make it one of the bestequipped physical laboratories in the world for carrying on scientific research.

\section{Scientific and Technical Work}

The work of the Bureau includes many branches of physics, chemistry, and engineering, such as mechanics, heat, optics, electricity, sound, metrology, metallurgy, radio, electronics, thermodynamics, aerodynamics, engineering (aeronautical, automotive, electrical, gas, hydraulic, mechanical, structural), also industrial technology (ceramics, leather, paper, petroleum, rubber, and textiles), including research and standardization, and offers valuable experience in these professions, combining as it does theoretical, experimental, and practical work. 


\section{Training in the Bureau}

The Bureau affords an excellent opportunity for training in scientific work, and its close connection with the industries makes Bureau experience valuable in industrial research. Many employees have found a Bureau position the stepping stone to some more highly remunerative one outside. Others who have remained in the service have been rewarded with steady advancement. It is generally recognized that the Government scientific and technical service is an excellent postgraduate training ground, and outside interests are ever on the alert to secure successful Government research workers.

\section{Educational opportunities}

Educational opportunities are afforded by the weekly meetings of the Bureau staff, meetings of the various divisions and sections, the atomic physics seminar, cooperative postgraduate study courses in physics, chemistry, mathematics, etc., conducted by members of the staff and others outside of official hours, special lectures by visiting scientists, and meetings of national societies. The advanced courses at the Bureau are accepted by several universities as credits toward a higher degree when combined with a moderate amount of additional work taken in residence at the university selected. In some cases facilities can be provided at the Bureau for carrying out an experimental research which can be used for a thesis. Junior assistants are offered the opportunity of continuing their college work at local universities. In fact, employees appointed to positions in the subprofessional service are expected to prepare themselves by suitable education in some branch of the Bureau's work for the broader field represented in positions of higher grades. The university courses are largely arranged to suit the convenience of persons in the Government service, and classes in most subjects are given in the late afternoon or evening.

\section{Library Facilities}

The National Bureau of Standards has a highly specialized scientific library of 40,000 volumes and free use of the other scientific collections in Washington. 
INFORMATION REGARDING APPOINTMENTS

Mode of Entrance

All positions on the staff of the National Bureau of Standards are subject to the competitive requirements of the civil-service rules and regulations. Only those candidates can be considered who have passed appropriate examinations and who are certified by the United States Civil Service Commission among the three highest eligibles on the register as vacancies arise.

Needs of the Service

For original appointment the demand is always much greater for junior assistants than for the higher grades, principally because, wherever possible, vacancies in the higher grades are filled through promotion. The bureau staff comprises approximately 775 professional, subprofessional, clerical, administrative, fiscal, and custodial positions. Naturally, in a force of this size vacancies often occur. The staff is also gradually increasing, so that there is frequent opportunity for the employment of young college men and women in scientific work.

\section{Entrance Salary}

All appointments are made at the entrance salary of the grade for which eligibles have qualified through civil-service examination.

\section{Duties}

No definite statement can be made as to the specific nature of the duties of a particular grade or position prior to offer of appointment. The duties are usually in connection with original investigations or testing in some field of the Bureau's work. While experimental testing usually forms the major part of the early work of new appointees in the junior grades, opportunities for research are afforded.

\section{Application}

Formal applications for examination in any of the several grades cannot be accepted until after an examination has been announced. Application is made on standard prescribed forms issued by the United States Civil Service Commission. 


\section{Examination}

Examinations for positions in the lower grades - are held occasionally throughout the country in practically every city of considerable size. Examinations for the higher grades are held from time to time as the needs of the service require. Applicants for the junior professional and subprofessional positions are required to report for a written examination. Applicants for positions of higher grade are not required to report for a written examination but are rated on their education, training, experience, writings (publications, reports, or thesis), and corroborative evidence.

\section{Notice of Examination}

Persons who desire to be notified of the announcement of an examination for a position of any grade or in any specialty in the National Bureau of Standards may place their names on file for the purpose with the United States Civil Service Commission or the National Bureau of Standards, Washington, D. C.

Announcements showing the exact dates on which the examinations will be held and giving full information regarding the requirements, places of examination, etc., will be mailed to the heads of appropriate departments of colleges and universities and other interested persons approximately one month in advance of the examination dates.

\section{Physical Examination}

In view of the benefits granted employees under employees' compensation and retirement legislation, persons appointed will be required to pass a physical examination by a physician in the Federal service before entering on duty. They must have such health and freedom from physical defects as will enable them to meet the physical standard which the Civil Service Commission deems necessary to perform the duties of the position.

\section{Member of Family Already in Government}

In view of present employment conditions, where there are already one or more members of a single family (living under the same roof) in the service of the District of Columbia or the United States, additional members of that family will not be appointed. 


\section{Senior Students}

Applications will be accepted from senior students in college and high school when an examination is announced, subject to their furnishing proof of actual graduation before entering on duty in case appointment is made.

\section{Citizenship and Sex}

All citizens of the United States, both men and women, who meet the requirements may enter these examinations; appointing officers, however, have the legal right to specify the sex desired in requesting certification of eligibles.

\section{Residence and Domicile}

To be eligible for permanent appointment to the apportioned service in Washington, D. C., applicants must have been actually domiciled, for at least one year next preceding the date of the examination, in the State or Territory in which they claim legal residence. Practically all positions on the Bureau staff are in the District of Columbia and are, therefore, subject to the above residence requirement.

\section{Temporary Appointment}

Temporary appointments are also made through civil-service examination and certification; that is, if there are eligibles on civil-service registers who are willing to accept temporary appointment, they must be given first opportunity for such positions. Temporary appointment of others mav be authorized by the United States Civil Service Commission in the event that there are no eligibles available for certification from existing lists, pending the announcement of an examination and the establishment of a new register of eligibles. There is, however, usually a surplus of civil-service eligibles available for certification, and there is seldom opportunity for such temporary appointment of others except in positions requiring highly specialized training and experience.

\section{Summer Appointment}

There are no special provisions for appointments to cover the summer-vacation period. A few such appointments can sometimes be made, but, in general, the statements above regarding civil-service requirements for temporary appointments apply to the summer positions as well. The Bureau's operations have to be conducted under a budget providing for fairly uniform maintenance of its work and staff 


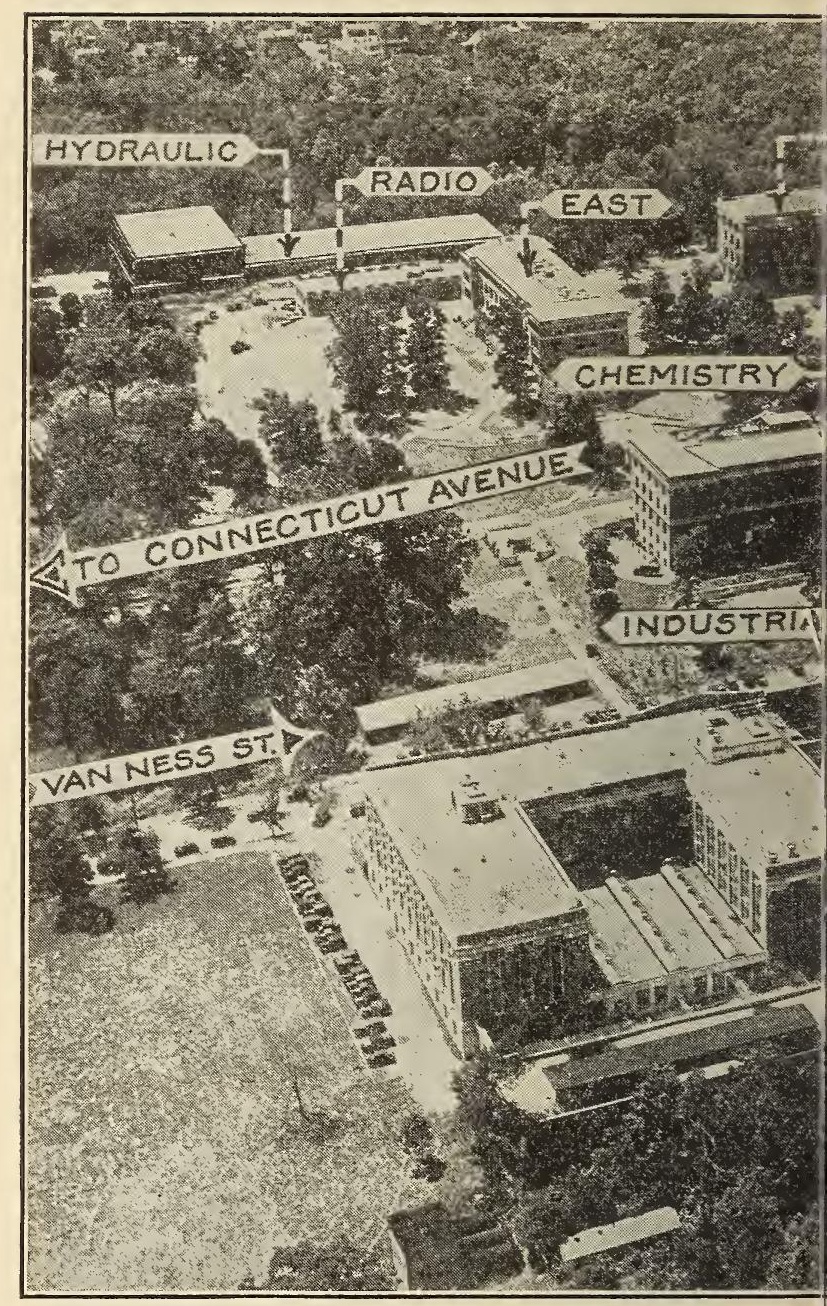





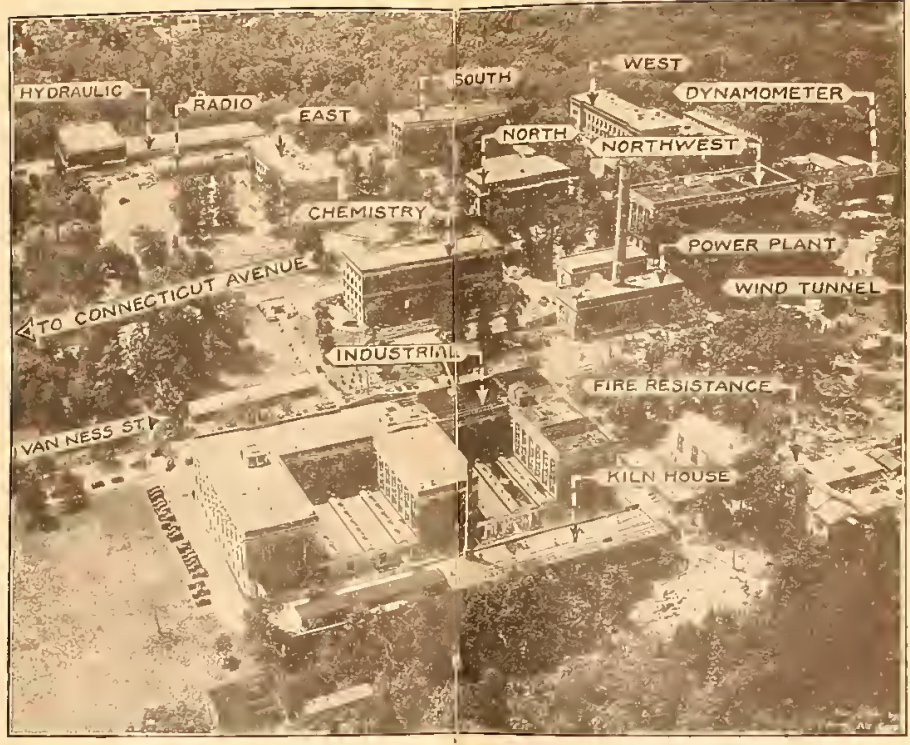


throughout the year. Forthermore, most of the work requires a considerable amount of experience before it can be carried on independently. The time required from experienced members of the staff in instructing and supervising new appointees makes employment for short periods uneconomical. In view of all these conditions, it is necessary to limit rather closely the number of summer appointments made.

\section{Research Associate Positions}

Technical problems arise in every industry. Some are of such pressing importance that an industry or group of technicians concerned may apply to the Bureau for cooperation. If facilities and other conditions are favorable, the Bureau may authorize the appointment of a research associate. The industrial or technical group allots funds for the purpose. A research worker is then sought either by the Bureau or the employing organization. If mutually acceptable, he is appointed as a research associate by the Director of the National Bureau of Standards. Usually the appointee is a technical or scientific graduate qualified to initiate and conduct research. The employing organization is usually an association of an entire industry or a specialized scientific or technical group. These appointments are made without reference to civil-service examination, rules, and regulations. In view of the small number of research associate assignments, in comparison with the regular staff, vacancies seldom arise in these positions.

\section{Nontechnical Positions}

There are also other classes of positions on the staff of the National Bureau of Standards, such as clerical, stenographic, administrative, mechanical, etc., but calls for such eligibles are infrequent and there is usually a sufficient supply of eligibles available to meet the demand of the service from current examinations conducted by the United States Civil Service Commission for the entire Government service. Requests for information concerning these positions should be addressed to the United States Civil Service Commission, Washington, D. C.

\section{Probationary Period}

All civil-service appointees to professional positions in this Bureau are required to serve a probationary period of one year. Appointees to nonprofessional positions will serve a probationary period 
of six months. At the expiration of the probationary period, the appointment becomes permanent if the employee's work and conduct have been satisfactory.

\section{QUALIFICATIONS REQUIRED FOR ENTRANCE}

The general requirements necessary for admittance to the examinations for the regular scientific and technical positions are given below. It is, of course, occasionally necessary to announce other special examinations, but these are usually of a highly specialized nature. The professional degrees must have been conferred by a college or university of recognized standing.

Junior Professional Grade (salary range, $\$ 2,000$ to $\$ 2,600)$

Physicist.-Graduation with a bachelor's degree with the completion of at least 118 semester-hours credit, such course to have included as a minimum mathematics through elementary differential equations, and at least 24 semester-hours of physics. Applicants are examined and rated on the subjects of general physics, mathematics through calculus, and practical questions on the optional subject chosen (electricity, heat, mechanics, optics, physical metallurgy, radio).

Chemist.-Graduation with a bachelor's degree, such degree requiring the completion of at least 118 credit-hours, 30 credit-hours of which must have been in chemistry. Applicants are examined and rated on the subjects of general chemistry and elementary physics and practical questions on the optional subject chosen (advanced inorganic chemistry, analytical chemistry, organic chemistry, physical chemistry).

Technologist.-Graduation with a degree with the completion of at least 118 credit-hours, such a course to have included the fundamentals of chemistry, mathematics, and engineering or physics. Applicants are examined and rated on the subjects of general chemistry and elementary physics, mathematics up to and including calculus, and practical questions on the optional subject chosen (ceramics, leather, paper, petroleum, rubber, and textile technology).

Engineer.-Graduation upon the completion of at least 118 semester-hours credit with a degree in engineering, preferably along the line of the optional chosen. Applicants are examined and rated on the 
subjects of general physics, mathematics, general engineering, and practical questions on the optional subject chosen (aeronautical, chemical, civil, electrical, hydraulic, mechanical, struictural steel and concrete).

Assistant Professional Grade (salary range, $\$ 2,600$ to $\$ 3,200$ )

In addition to meeting the preliminary requirements for the junior professional grade, applicants must have had at least two years of subsequent experience in work of a research or scientific character in the optional selected, showing a fair degree of progression in duties and responsibilities and some aptitude for investigative work; provided, that one year of graduate work will be accepted in lieu of each year of the required experience.

Associate Professional Grade (salary range, $\$ 3,200$ to $\$ 3,800$ )

In addition to meeting the preliminary requirements for the junior professional grade, applicants must show that they have had at least three years of subsequent experience in specialized research or developmental work and should submit evidence to show the quality of work accomplished and their ability to assume important responsibilities and to carry on difficult scientific work in the optional under which they apply. Appointment in this grade requires professional attainment of a high order. Applicants may substitute one year of postgraduate work for each year of the required experience, but in order to qualify entirely on the basis of academic work an applicant must have received the doctor's degree.

Full Professional Grade (salary range, $\$ 3,800$ to $\$ 4,600$ )

In addition to meeting the preliminary requirements for the junior professional grade, applicants must show that they have had at least five years' experience subsequent to graduation and of a scientific or investigative nature in the optional selected. The training and experience must have been sufficient to demonstrate ability to perform highly specialized and extremely difficult scientific or investigative work, must show a high degree of progression, scientific research successfully accomplished, and ability to assume increasingly important responsibilities. 
Higher Professional Grades (salary range, $\$ 4,600$ to
$\$ 9,000$ )

Vacancies in the higher professional grades are usually filled by promotion, and it is seldom necessary to make appointments in these grades. Applicants for these positions must show broad fundamental scientific education, extended experience, demonstrated proficiency in the field of science involved, and exceptional executive ability. Examinations in the higher grades are announced only as the needs of the service require, and then only in highly specialized fields.

Minor Subprofessional Grade (salary range, $\$ 1,020$ to $\$ 1,380$ )

Applicants for the position of minor physical science aid must show that they have graduated from a 4-year high-school course or completed 14 units of high-school work accepted for college entrance, and that their high-school work included at least a 1-year course in either physics or chemistry. Applicants are examined and rated on the subjects of elementary algebra and geometry, and elementary physics or chemistry.

Under Subprofessional Grade (salary range, $\$ 1,260$ to $\$ 1,620)$

Applicants for the position of under-physical science aid must have completed at least 30 credithours of college work, which shall have included as a minimum either a 6-hour course in college physics or a 6 -hour course in college chemistry. Applicants are examined and rated on the subjects of general chemistry or elementary physics, mathematics through trigonometry, mechanical drawing, or essay (to be handed to the examiner on the day of the examination), and education and experience.

Junior Subprofessional Grade (salary range, $\$ 1,440$ to $\$ 1,800)$

Applicants for the position of junior physical science aid must have completed at least 60 credithours of college work, such college course to have included as a minimum either a 6-hour course in college physics or a 6-hour course in college chemistry. Applicants are examined and rated on the subjects of general chemistry or elementary physics, mathematics through trigonometry, mechanical drawing, or essay (to be handed to the examiner on the day of the examination), and education and experience. 
Assistant Subprofessional Grade (salary range, $\$ 1,620$ to $\$ 1,980)$

Applicants for the position of assistant physical science aid must show that they have completed at least 90 credit-hours of study in a college or university of recognized standing and that they have majored in the optional subject selected in the examination (advanced general physics, ceramics, chemical engineering, chemistry, civil and mechanical engineering, electrical engineering, paper technology, physical metallurgy, physics and chemistry, textile technology). Applicants are examined and rated on the subjects of general chemistry and elementary physics, mathematics including differential calculus, mechanical drawing, or essay (to be handed to the examiner on the day of the examination), and education and experience.

Higher Subprofessional Grades (salary range, $\$ 1,800$ to $\$ 3,200$ )

It is seldom, if ever, necessary to hold examinations in the higher subprofessional grades except in unusual cases where special training and experience are required. Employees in the subprofessional service engaged in laboratory work are usually promoted from the assistant subprofessional grade to the junior professional grade upon receiving a college degree. The higher subprofessional grades are composed principally of mechanical or other types of positions not in line for promotion to the professional service.

\section{GENERAL INFORMATION}

\section{Working Hours}

The regular hours for employees on the scientific staff of the National Bureau of Standards are from 8:30 a.m. to 4 p.m. with one-half hour out for luncheon. On Saturdays the working hours are from 8:30 a.m. to $12: 30$ p.m. without intermission.

\section{Leave of Absence}

Employees of the National Bureau of Standards are granted 15 days, exclusive of Sundays and holidays, of annual leave in each year. During sickness of an employee salary may be paid for a period not in excess of 30 days annually.

\section{Advancement}

The positions on the scientific staff form a continuous series from the entrance grade to the highest, subject to the limitations placed by the number of vacancies occurring. Promotion is possible from 
one grade to another without further examination other than the entrance examination, subject, of course, to the individual employee's efficiency, training, and accomplishments, and to the funds available for making promotion.

\section{Retirement}

Classified employees who have reached the retirement age and have served 15 years are entitled to retirement with annuity. A deduction of $3 \frac{1}{2}$ percent is made from monthly salary to provide for this annuity, which will be returned with 4 percent interest, compounded annually, to persons leaving the service before retirement. The retirement age for professional employees is 70 years, with optional retirement at 68 years.

\section{Specimen Examination Papers}

The National Bureau of Standards does not distribute specimen sets of previous examination papers. The character of the examinations for the various classes of positions is sufficiently indicated under the separate headings in this publication.

\section{Transportation to New Appointees}

Persons accepting appointments must report to Washington, D. C., or assigned post of duty without cost to the Government.

\section{Welfare}

Provision is made for the individual welfare of the Bureau employees. Voluntary first aid is rendered in all principal buildings, and for those injured in line of duty care is provided in accordance with the provisions of the Federal Compensation Act.

\section{Recreation}

There are tennis courts at the Bureau, and facilities for golf, tennis, bathing, baseball, polo, skating, and other sports are provided in the public parks. The Potomac River is much used for canoeing, swimming, and its banks for camping and hiking. The Library of Congress, National Academy of Sciences, National Museum, art galleries, Zoological Park, and many other civic institutions peculiar to the National Capital afford unusual opportunities for culture and recreation.

\section{Cost of Living in Washington}

The cost of living in Washington is about the same as in other large cities of the country. The average cost of room and board in the vicinity of the National 
Bureau of Standards is approximately $\$ 40$ to $\$ 50$ per month, including two meals per day. Rentals for apartments and houses would probably range from $\$ 55$ per month and upward, depending upon the size, location, etc.

\section{Salary Ranges}

The following table gives the salary steps attached to the various grades and positions under the classification act:

\section{Professional service}

\begin{tabular}{|c|c|c|c|c|c|c|c|c|}
\hline$\underset{\overparen{D}}{\mathbb{Z}}$ & Descriptive title & \multicolumn{7}{|c|}{ Salary rates in dollars } \\
\hline 1 & Junior _ & 2000 & 2100 & 2200 & 2300 & 2400 & 2500 & 2600 \\
\hline 2 & Assistant & 2600 & 2700 & 2800 & 2900 & 3000 & 3100 & 3200 \\
\hline 3 & Associate.- & 3200 & 3300 & 3400 & 3500 & 3600 & 3700 & 3800 \\
\hline 4 & Fuil _...... & 3800 & 4000 & 4200 & 4400 & 4600 & & \\
\hline 5 & Senior -- & 4600 & 4800 & 5000 & 5200 & 5400 & & \\
\hline 6 & Principal_ & 5600 & 5800 & 6000 & 6200 & 6400 & & \\
\hline 7 & Head _.... & 6500 & 7000 & 7500 & & & & \\
\hline 8 & Chief_. & 8000 & 8500 & 9000 & & & & \\
\hline
\end{tabular}

Subprofessional service

\begin{tabular}{|c|c|c|c|c|c|c|c|c|}
\hline 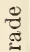 & Descriptive title & \multicolumn{7}{|c|}{ Salary rates in dollars } \\
\hline 1 & Minor & 1020 & 1080 & 1140 & 1200 & 1260 & 1320 & 1380 \\
\hline 2 & Under. - & 1260 & 1320 & 1380 & 1440 & 1500 & 1560 & 1620 \\
\hline 3 & Junior & 1440 & 1500 & 1560 & 1620 & 1680 & 1740 & 1800 \\
\hline 4 & Assistant & 1620 & 1680 & 1740 & 1800 & 1860 & 1920 & 1980 \\
\hline 5 & Main & 1800 & 1860 & 1920 & 1980 & 2040 & 2100 & 2160 \\
\hline 6 & Senior & 2000 & 2100 & 2200 & 2300 & 2400 & 2500 & 2600 \\
\hline 7 & Principal & 2300 & 2400 & 2500 & 2600 & 2700 & 2800 & 2900 \\
\hline 8 & Chief . ........ & 2600 & 2700 & 2800 & 2900 & 3000 & 3100 & 3200 \\
\hline
\end{tabular}


Clerical, administrative, and fiscal service

\begin{tabular}{|c|c|c|c|c|c|c|c|c|}
\hline 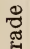 & Descriptive title & \multicolumn{7}{|c|}{ Salary rates in dollars } \\
\hline 1 & Under. & 1260 & 1320 & 1380 & 1440 & 1500 & 1560 & 1620 \\
\hline 2 & Junior & 1440 & 1500 & 1560 & 1620 & 1680 & 1740 & 1800 \\
\hline 3 & Assistant... & 1620 & 1680 & 1740 & 1800 & 1860 & 1920 & 1980 \\
\hline 4 & Main ........ & 1800 & 1860 & 1920 & 1980 & 2040 & 2100 & 2160 \\
\hline 5 & Senior........ & 2000 & 2100 & 2200 & 2300 & 2400 & 2500 & 2600 \\
\hline 6 & Principal & 2300 & 2400 & 2500 & 2600 & 2700 & 2800 & 2900 \\
\hline 7 & $\begin{array}{l}\text { Assistant administra- } \\
\text { tive }\end{array}$ & 2600 & 2700 & 2800 & 2900 & 3000 & 3100 & 3200 \\
\hline 8 & Associate administra- & 2900 & 3000 & 3100 & 3200 & 3300 & 3400 & 3500 \\
\hline 9 & Full administrative & 3200 & 3300 & 3400 & 3500 & 3600 & 3700 & 3800 \\
\hline 10 & Senior administrative & 3500 & 3600 & 3700 & 3800 & 3900 & 4000 & 4100 \\
\hline 11 & $\begin{array}{l}\text { Principal administra- } \\
\text { tive }\end{array}$ & 3800 & 4000 & 4200 & 4400 & 4600 & & \\
\hline 12 & Head administrative. & 4600 & 4800 & 5000 & 5200 & 5400 & & \\
\hline 13 & Chief administrative. & 5600 & 5800 & 6000 & 6200 & 6400 & & \\
\hline 14 & Executive & 6500 & 7000 & 7500 & & & & \\
\hline 15 & Senior executive.....- & 8000 & 8500 & 9000 & & & & \\
\hline
\end{tabular}

\section{Custodial service}

\begin{tabular}{|c|c|c|c|c|c|c|c|c|}
\hline ర్లై & Descriptive title & \multicolumn{7}{|c|}{ Salary rates in dollars } \\
\hline 1 & Junior messenger & 600 & 660 & 720 & 780 & 840 & & \\
\hline 2 & Office laborer & 1080 & 1140 & 1200 & 1260 & 1320 & 1380 & \\
\hline 3 & Minor & 1200 & 1260 & 1320 & 1380 & 1440 & 1500 & \\
\hline 4 & Under... & 1320 & 1380 & 1440 & 1500 & 1560 & 1620 & 1680 \\
\hline 5 & Junior & 1500 & 1560 & 1620 & 1680 & 1740 & 1800 & 1860 \\
\hline 6 & Assistant. & 1680 & 1740 & 1800 & 1860 & 1920 & 1980 & 2040 \\
\hline 7 & Main & 1860 & 1920 & 1980 & 2040 & 2100 & 2200 & 2300 \\
\hline 8 & Senior & 2000 & 2100 & 2200 & 2300 & 2400 & 2500 & 2600 \\
\hline 9 & Principal & 2300 & 2400 & 2500 & 2600 & 2700 & 2800 & 2900 \\
\hline 10 & Chief & 2600 & 2700 & 2800 & 2900 & 3000 & 3100 & 3200 \\
\hline
\end{tabular}


